\author{
건물 및 영양소 섭취량 제한이 농후사료 급여 비율이 높은 착유우의 \\ 생산성에 미치는 영향 \\ 조영석・임종수 · 장원석 · 김명화 · 이상락 \\ 건국대학교 동물생명과학대학
}

\title{
Effect of Restriction of Dry Matter and Nutrient Intakes on Productivity of Holstein Lactating Cows Offered High Levels of Concentrate
}

\author{
Young Seok Cho, Jong Su Rim, Won Seok Jang, Myeong Hwa Kim and Sang Rak Lee \\ College of Animal Bioscience \& Technology, Konkuk University
}

\begin{abstract}
Effects of dry matter intake restriction to the level of recommend by NRC (2001) on intake balance of dry matter and nutrients in Holstein lactating cow were evaluated. 24 lactating cows were divided into two groups and individually fed one of the TMR offered as ad libitum (control) and restricted amount (treatment) as recommended by NRC (2001). Milk yield including 4\% FCM and FPCM were showed higher tendency in treatment group then those of control group. Also, intakes of dry matter, net energy and metabolizable protein were tended to be higher in treatment group then control group. Actual dry matter and net energy intakes in control group were higher $(p<0.001)$ then those of recommended amount by NRC (2001), whereas no significant differences in treatment group. The estimated $\mathrm{NE}_{\mathrm{L}}$ allowable milk yield were lower $(\mathrm{p}<0.001)$ in both control and treatment group than those of recommended by NRC (2001). It was concluded that to allow ad libitum feeding of diet containing high levels of concentrate to the lactating cows might decrease the efficiency of feed nutrients and hence result in no positive effect on productivity of milk.

(Key words : Intake control, Dry matter intake, Net energy intake, Metabolizable protein intake, Milk production, Holstein lactating cow)
\end{abstract}

\section{I. 서 론}

2001년 12월에 National Research Council (NRC)은 그 간의 연구결과들과 현장에서의 적용사례들을 바탕으 로 착유우에 대한 새로운 모델을 적용한 사양표준 (Nutrient Requirements of Dairy Cattle $7^{\text {th }}$ revised edition; NRC, 2001)을 출판하였고, 이 새로운 NRC 사 양표준에 기초하여 우리나라에서도 한국유우사양표준 을 2002년도에 새롭게 설정하였다. 한편, Cornell대학 에서도 2003년도에 새로운 모델을 적용한 The Net Carbohydrate and Protein System for Evaluating Herd Nutrition and Nutrient Excretion(CNCPS version 5.0)을 발표하였다. 이들 사양표준이나 영양소섭취 평가모델 은 우리나라 젖소에 대한 영양소 급여량을 결정하는 가장 중요한 기준으로 활용되고 있다.

그러나 $\mathrm{NRC}$ 나 $\mathrm{CNCPS}$ 의 모델들은 주로 북미의 젖 소 사양 환경에서 얻어진 자료를 바탕으로 개발한 것 이어서 우리나라에서의 사양 환경, 즉, 상대적으로 농 후사료 급여비율이 높고 입자도가 낮은 조사료를 많
이 급여하는 사양 환경에서는 잘 맞지 않는 경우가 있다. 저자들은 우리나라의 착유우들을 대상 (12농가 430 두)으로 건물 및 영양소 섭취량을 조사한 연구 ( $\operatorname{Rim}$ 등, 2008)에서 우리나라의 착유우들은 $\mathrm{NRC}$ 나 CNCPS 모델에서 제시한 건물 및 영양소 섭취요구량 을 크게 상회하는 섭취량을 나타내는 것을 확인하였 고 사료 중 농후사료의 비율이 높은 것이 그 원인으 로 분석하였다.

일반적으로 농후사료 급여량을 증가시키면 조사료 섭취량이 감소되지만 총 건물섭취량은 증가하는 경향 을 보여 결과적으로 유생산량은 증가한다 (Gordon, 1981; Mayne과 Gordon, 1984; O’Mara 등, 1998; Rinne 등, 1999). 그러나 사료의 소화율은 사료섭취량이 증가 할수록 감소하므로 (Tyrrell과 Moe, 1975) 유생산량을 높일 목적으로 농후사료를 과다하게 급여하는 것은 영양소의 낭비를 초래하게 될 뿐만 아니라 반추위내 의 발효환경을 나쁘게 함으로써 착유우의 건강과 번 식에도 부정적인 영향을 미치게 된다.

착유우에게는 유생산량 뿐만 아니라 건강과 영양소

Corresponding author: Sang Rak Lee, College of Animal Bioscience \& Technology, Konkuk University, 1 Hwayang-dong, Gwangjin-gu, Seoul, 143-701, Korea.

Tel: 02-450-3696, Fax: (02) 458-2124, E-mail: leesr@konkuk.ac.kr 
의 이용 효율을 고려한 사료의 급여가 매우 중요하다. 이러한 관점에서 볼 때 현재 우리나라 착유우들의 건 물 및 영양소의 섭취량이 $\mathrm{NRC}$ 나 $\mathrm{CNCPS}$ 의 모델보다 높게 나타나는 것이 착유우의 종합적인 생산성에 적 합한 것인지 아니면 과다한 것인지에 대한 검토가 필 요하다.

따라서 본 실험은 농후사료 급여 비율이 약 $65 \%$ 이 상인 착유우에 있어 NRC(2001) 영양소 권장량을 충 족시키는 조건에서 건물 및 영양소 섭취를 제한하는 것이 착유우의 영양소 균형 및 생산성에 미치는 영향 을 조사하기 위하여 실시하였다.

\section{ㅍ. 재료 및 방법}

\section{1. 공시동물}

본 실험은 2005년 5월 6일부터 2005년 5월 17 까지 12 일 동안 경기도 파주시에 위치한 건국대학교 종합 실습목장의 톱밥우사에서 홀스타인 착유우 24 두를 공 시하여 실시하였다. 사료는 TMR로 제조하여 individual electronic feeding gates (American Calan, Inc., Northwood, $\mathrm{NH}$ )를 통하여 각 개체별로 예상 일일 건물섭취 량의 약 $105 \%$ 를 오전 9 시와 오후 5 시에 나누어 급여 하였다.

본 실험을 시작하기 전에 feeding gate와 실험사료 및 사료급여 방법에 대한 적응을 위하여 2주 동안 예 비실험을 실시하였다.

예비 및 본 실험기간 동안의 평균온도는 $14.4^{\circ} \mathrm{C}$, 최 고온도는 $21.4^{\circ} \mathrm{C}$, 최저온도는 $7.9^{\circ} \mathrm{C}$, 상대습도는 $70.8 \%$ 를 나타내었다.

\section{2. 실험설계 및 진행}

예비실험기간 동안 조사한 착유우의 체중, body condition score (BCS), 유량 및 유성분 등의 가축정보 를 Table 1에 나타내었다. 이를 바탕으로 하여 24 두의 착유우를 각 12 두씩 대조구와 시험구의 2 개 그룹으로 임의 배치하였다.

대조구와 시험구의 실험우 모두에게는 TMR을 기본 으로 하고 각 개체의 유생산 능력에 따라 배합사료를 농후사료 자동급이기를 이용하여 추가적으로 급여하 였으나 대조구에는 TMR을 무제한 급여하였고, 시험 구에는 NRC (2001)의 건물섭취 권장량의 $100 \%$ 수준으 로 맞추어 급여하기 위하여 $\mathrm{NRC}(2001)$ 이 권장하는 에너지 및 단백질 수준의 $100 \% 105 \%$ 를 충족하는 조 건에서 TMR 급여를 제한하였다.

실험우에게 급여한 $\mathrm{TMR}$ 의 배합비와 화학성분은 Table 2에 나타내었다. 사료섭취량은 feeding gate를 이 용하여 개체별로 측정하였다. 착유는 매일 오전 4시와
Table 1. Descriptions of experimental Holstein lactating cows and recommended dry matter and nutrient intake by NRC (2001) in this study

\begin{tabular}{lrc}
\hline \multicolumn{1}{c}{ Items } & Control $^{1)}$ & Treatment $^{2)}$ \\
\hline \hline Number of cows & 12 & 12 \\
\hline Animal descriptions & & \\
Body weight, kg & $626.0 \pm 90.2^{3)}$ & $650.0 \pm 95.2$ \\
Parity & $2.6 \pm 1.3$ & $2.6 \pm 1.4$ \\
Body condition score & $2.8 \pm 0.5$ & $2.7 \pm 0.6$ \\
Days in milk, d & $172.3 \pm 86.2$ & $178.3 \pm 79.3$ \\
Days pregnant, d & $105.8 \pm 20.9$ & $120.5 \pm 33.9$ \\
Milk yield, kg/d & $29.0 \pm 6.1$ & $30.4 \pm 7.4$ \\
Milk fat, \% & $3.57 \pm 0.70$ & $3.73 \pm 0.83$ \\
Milk protein, \% & $3.37 \pm 0.34$ & $3.33 \pm 0.22$ \\
\hline
\end{tabular}

Recommended dry matter and nutrients intake

\begin{tabular}{lcc} 
Dry matter intake, $\mathrm{kg} / \mathrm{d}$ & $21.4 \pm 2.8$ & $22.5 \pm 2.5$ \\
$\begin{array}{l}\text { Net energy for lactation, } \\
\text { Mcal/d }\end{array}$ & $30.9 \pm 4.8$ & $32.3 \pm 4.6$ \\
Metabolizable protein, g/d & $2350 \pm 362$ & $2411 \pm 396$ \\
\hline
\end{tabular}

${ }^{1)}$ Control : Lactating cows fed ad libitum TMR.

${ }^{2)}$ Treatment : Lactating cows fed restricted TMR.

${ }^{3)}$ Mean \pm standard error.

오후 4시에 2회 실시하였고, 자동유량기록장치 (a-Laval, Denmark)를 이용하여 유량을 측정하였다. 오전 및 오 후 착유 시에 유성분 분석을 위하여 $20 \mathrm{ml}$ 의 우유를 채취하여 냉장상태로 즉시 분석실로 운반하였다.

\section{3. 분석방법}

TMR의 dry matter(DM), ash, crude protein (CP), ether extracts (EE), acid detergent fiber(ADF) 및 acid detergent lignin (ADL) 성분은 A.O.A.C. (1990)의 방법에 따라 분석하였고, neutral detergent fiber (NDF)는 Mertens 등 (2002)의 방법에 따라 분석하였으며, neutral detergent insoluble crude protein (NDICP)과 acid detergent insoluble crude protein (ADICP)은 Licitra 등(1996)의 분 석방법에 따라 분석하였다.

유성분은 자동유성분분석기 (Milco-scan 'System 4300'; Foss Electric, Denmark)를 이용하여 분석하였고 오전과 오후의 평균값을 산출하였다.

\section{4. 영양소 균형 평가}

NRC의 Nutrients Requirement of Dairy Cattle Program (version 1.0)을 이용하여 개체 별 건물섭취 (dry matter intake, DMI), 정미에너지 (net energy for lactation, $\mathrm{NE}_{\mathrm{L}}$ ), 대사단백질 (metabolizable protein, $\mathrm{MP}$ )의 균형 
Table 2. A formula and chemical composition of experimental diet

\begin{tabular}{|c|c|c|}
\hline Items & $\begin{array}{l}\text { Concen- } \\
\text { trate }\end{array}$ & $\begin{array}{l}\text { Basal } \\
\text { TMR }\end{array}$ \\
\hline \multicolumn{3}{|l|}{ Ingredients } \\
\hline Corn cracked, \% & 37.0 & 13.5 \\
\hline Wheat, \% & 8.7 & 1.5 \\
\hline Molasses, \% & 4.0 & 0.7 \\
\hline Lupin seed, \% & 14.8 & 2.6 \\
\hline Soybean meal, \% & 9.0 & 1.6 \\
\hline Corn gluten meal, \% & 3.0 & 0.5 \\
\hline Coconut meal, \% & 5.0 & 0.9 \\
\hline Palm meal, \% & 3.0 & 0.5 \\
\hline Cotton seed, $\%$ & - & 7.7 \\
\hline Wheat bran, \% & 11.0 & 10.3 \\
\hline Alfalfa hay, \% & - & 10.5 \\
\hline Rye straw, \% & - & 6.9 \\
\hline Rye grass silage, $\%$ & - & 41.9 \\
\hline Limestone, \% & 2.9 & 0.5 \\
\hline Dicalcuim phosphate, $\%$ & 0.5 & 0.1 \\
\hline Salt, \% & 0.5 & 0.1 \\
\hline Vitamin mixture, \% & 0.6 & 0.1 \\
\hline \multicolumn{3}{|l|}{ Chemical compositions } \\
\hline Dry matter, \% & 88.4 & 60.3 \\
\hline Crude protein, \%DM & 20.8 & 15.1 \\
\hline Ether extract, \%DM & 3.2 & 4.2 \\
\hline Nonfibrous carbohydrate, \%DM & 47.9 & 32.1 \\
\hline Neutral detergent fiber, $\% \mathrm{DM}$ & 25.3 & 44.0 \\
\hline Forage neutral detergent fiber, $\% \mathrm{DM}$ & - & 24.3 \\
\hline Acid detergent fiber, \%DM & 9.5 & 25.4 \\
\hline Acid detergent lignin, \%DM & 3.9 & 7.3 \\
\hline Net energy for lactation ${ }^{1)}, \mathrm{Mcal} / \mathrm{kgDM}$ & 2.0 & 1.6 \\
\hline
\end{tabular}

평가 및 유생산성 평가를 실시하였다.

가축정보 중 분만간격, 초산분만 개월령 및 일당 증 체량은 각각 12 개월, 24 개월 및 $0 \mathrm{~g}$ /일을 일률적으로 적용하였고, 착유우의 성숙 체중과 송아지 출생 시 체 중은 NRC (2001)가 제시하는 자료를 이용하였다. 일반 성분 및 $\mathrm{aNDF}, \mathrm{ADF}, \mathrm{ADL}, \mathrm{NDICP}, \mathrm{ADICP}$ 는 본 연구 에서 직접 분석한 자료를 이용하였으며, processing adjustment factor $(\mathrm{PAF})$, 단백질 분획 $(\% \mathrm{CP})$, Protein Digestion Rate (\%hr), RUP Digest (\%), Fat Digest (\%), NDF Digest (\%)는 NRC (2001)의 feed library에 수록된 값을 이용하였다.

\section{5. 통계분석}

대조구와 시험구의 NRC (2001)를 이용한 건물 및 영양소 섭취 균형 평가 결과는 SAS (Strategic Application Software) statistic package program(2001, release 8.02 version)의 paired t-test procedure를 이용하여 유의성을 검정하였고, 건물 및 영양소 섭취량과 유생산성은 $\mathrm{SAS}$ 의 t-test procedure를 이용하여 유의성을 검정하 였다.

\section{III. 결 과}

Table 3에 기초사료인 TMR을 무제한 (대조구) 또는 제한(시험구) 급여한 착유우의 유생산량을 나타내었 다. 대조구와 시험구의 유생산량은 각각 $27.6 \mathrm{~kg}$ /일/두, $28.1 \mathrm{~kg} /$ 일/두로 시험구가 높은 경향을 나타내었으나 통계적 유의차는 나타나지 않았다. 대조구의 유지방 생산량은 $1.0 \mathrm{~kg}$ /일/두로 시험구의 $1.1 \mathrm{~kg}$ /일/두 보다 낮 게 나타났지만 통계적 유의차는 나타나지 않았다. 대 조구와 시험구의 유단백 생산량은 각각 $0.9 \mathrm{~kg} /$ 일/두, $0.9 \mathrm{~kg}$ /일/두로 나타났다. 시험구의 $4 \% \mathrm{FCM}$ 과 $\mathrm{FPCM}$ 생산량은 각각 $28.0 \mathrm{~kg}$ /일/두, $27.8 \mathrm{~kg}$ /일/두로 대조구의

Table 3. Milk production of Holstein lactating cows fed ad libitum or restricted TMR

\begin{tabular}{|c|c|c|c|}
\hline Items & Control $^{1)}$ & Treatment $^{2)}$ & $\begin{array}{c}\left.\text { Significances }{ }^{6}\right) \\
\text { (control vs. treatment) }\end{array}$ \\
\hline Milk yield, kg/d & $27.6 \pm 2.0^{3)}$ & $28.1 \pm 2.3$ & NS \\
\hline $4 \% \mathrm{FCM}^{4)}$ yield, $\mathrm{kg} / \mathrm{d}$ & $26.1 \pm 2.0$ & $28.0 \pm 2.3$ & NS \\
\hline FPCM $^{5)}$ yield, kg/d & $26.4 \pm 1.9$ & $27.8 \pm 2.2$ & NS \\
\hline Fat yield, $\mathrm{kg} / \mathrm{d}$ & $1.0 \pm 0.1$ & $1.1 \pm 0.1$ & NS \\
\hline Protein yield, $\mathrm{kg} / \mathrm{d}$ & $0.9 \pm 0.1$ & $0.9 \pm 0.1$ & NS \\
\hline
\end{tabular}

\footnotetext{
${ }^{1)}$ Control : Lactating cows fed ad libitum TMR.

${ }^{2)}$ Treatment : Lactating cows fed restricted TMR

${ }^{3)} \mathrm{Mean} \pm$ standard error.

4) $4 \%$ fat corrected milk $(4 \% \mathrm{FCM})$ was calculated from $4 \% \mathrm{FCM}, \mathrm{kg} / \mathrm{d}=0.4 \times$ milk yield, $\mathrm{kg} / \mathrm{d}+15 \times$ milk fat, $\mathrm{kg} / \mathrm{d}(\mathrm{Gaines}$, 1928).

${ }^{5)}$ Fat-protein corrected milk(FPCM) was calculated from FPCM, $\mathrm{kg} / \mathrm{d}=($ milk yield, $\mathrm{kg} / \mathrm{d}) \times(0.337+0.116 \times$ milk fat, $\%+$ 0.06 $\times$ milk protein, \%) (CVB, 1990).

${ }^{6}$ Significances were analyzed by t-test(NS, not significant).
} 
$26.1 \mathrm{~kg} /$ 일/두, $26.4 \mathrm{~kg}$ /일/두 보다 높은 경향을 나타내 었으나 통계적 유의차는 나타나지 않았다.

Table 4에 건물, 비유정미에너지 및 대사단백질의 실 제 섭취량과 $\mathrm{NRC}$ (2001)의 권장 섭취량을 나타내었다.

대조구의 실제 건물섭취량은 $23.8 \mathrm{~kg}$ /일/두로 시험구 의 $22.7 \mathrm{~kg}$ /일/두 보다 많이 섭취하였으며, NRC (2001) 의 건물섭취 권장량은 대조구가 $21.3 \mathrm{~kg}$ /일/두로 시험 구의 $22.2 \mathrm{~kg}$ /일/두보다 낮게 나타났으나 통계적 유의 차는 나타나지 않았다. 대조구의 실제 건물섭취량은 $\mathrm{NRC}$ (2001)의 건물섭취 권장량보다 유의한 증가가 나 타났으며 $(\mathrm{p}<0.01)$, 처리구의 실제 건물섭취량과 $\mathrm{NRC}$ (2001)의 건물섭취 권장량은 유사하게 나타났다.

$\mathrm{NRC}$ (2001)가 추정한 대조구의 비유정미에너지 $\left(\mathrm{NE}_{\mathrm{L}}\right)$ 섭취량은 $36.2 \mathrm{Mcal} /$ 일/두로 시험구의 $34.9 \mathrm{Mcal} /$ 일/두 보다 높은 경향을 나타내었으며, 대조구와 시험구의 $\mathrm{NE}_{\mathrm{L}}$ 섭취권장량은 각각 $30.0 \mathrm{Mcal} /$ 일/두, $31.2 \mathrm{Mcal} /$ 일/ 두로 시험구가 높은 경향을 나타내었으나 통계적 유 의차는 나타나지 않았다. NRC (2001)가 추정한 대조구 의 $\mathrm{NE}_{\mathrm{L}}$ 섭취량은 $\mathrm{NRC}(2001)$ 의 $\mathrm{NE}_{\mathrm{L}}$ 섭취권장량 보다 유의하게 높게 나타났으나 $(\mathrm{p}<0.001)$ 시험구에서는 유 의한 차이가 나타나지 않았다.

$\mathrm{NRC}$ (2001)가 추정한 대조구의 대사단백질 (MP) 섭 취량은 $2308 \mathrm{~g} /$ 일/두로 시험구의 $2224 \mathrm{~g} /$ 일/두 보다 높 은 경향을 나타내었으며, 대조구와 시험구의 MP 섭취 권장량은 각각 $2191 \mathrm{~g}$ /일/두, $2136 \mathrm{~g}$ /일/두로 대조구가 높은 경향을 나타내었으나 통계적 유의차는 나타나지 않았다. NRC (2001)가 추정한 대조구와 시험구의 MP 섭취량은 $\mathrm{NRC}$ (2001)의 MP 섭취권장량 보다 모두 높
게 나타났으나 통계적 유의차는 나타나지 않았다.

Table 5에 NRC(2001)의 모델을 이용하여 산출한 $\mathrm{NE}_{\mathrm{L}}$ 과 $\mathrm{MP}$ 의 allowable milk yield (AMY)를 나타내었 다. 대조구와 시험구의 유생산량은 각각 $27.6 \mathrm{~kg}$ /일/두, $28.1 \mathrm{~kg}$ /일/두로 시험구가 높은 경향을 나타내었으나 통계적 유의차는 나타나지 않았다. 대조구와 시험구의 $\mathrm{NE}_{\mathrm{L}} \mathrm{AMY}$ 는 각각 $36.1 \mathrm{~kg}$ /일/두, $33.2 \mathrm{~kg}$ /일/두로 대조 구가 높은 경향을 나타내었고, MP AMY는 $29.9 \mathrm{~kg}$ /일, $29.0 \mathrm{~kg}$ /일로 유사하게 나타났다. 대조구와 시험구의 NEL AMY는 모두 실제 유생산량보다 높게 나타났고 $(\mathrm{p}<0.001), \mathrm{MP} \mathrm{AMY}$ 도 모두 실제 유생산량보다 높은 경향을 나타내었다.

\section{VI. 고 찰}

기초사료인 $\mathrm{TMR}$ 을 무제한(대조구) 또는 제한(시험 구) 급여한 착유우에 대하여 NRC (2001) 모델로 건물 섭취 및 영양소 균형을 평가 한 결과 건물섭취량은 $\mathrm{NRC}$ (2001)가 추정한 권장량보다 실제 섭취량이 대조 구는 $12 \%$ 를 더 섭취하였고 $(\mathrm{p}<0.01)$ 시험구는 약 $2 \%$ 를 더 섭취하는 것으로 나타났다. 따라서 $\mathrm{NE}_{\mathrm{L}}$ 섭취량 도 권장량보다 대조구 및 시험구 모두 $22 \%$ 및 $13 \%$ 를 더 섭취하는 것으로 나타났다 $(\mathrm{p}<0.001)$. 이러한 결과 는 저자들의 선행연구 $(\operatorname{Rim}$ 등, 2008)에서도 확인된 현상이다. MP 섭취량은 $\mathrm{NRC}(2001)$ 가 추정한 $\mathrm{MP}$ 권 장량보다 대조구 및 시험구가 각각 $6 \%, 5 \%$ 를 더 많 이 섭취한 것으로 나타났으나 유의한 차이는 없었다. $\mathrm{NE}_{\mathrm{L}}$ 및 $\mathrm{MP}$ 섭취량으로부터 유지, 임신에 필요한 $\mathrm{NE}_{\mathrm{L}}$

Table 4. Evaluation of dry matter and nutrient intakes of Holstein lactating cows fed ad libitum or restricted TMR through NRC (2001)

\begin{tabular}{|c|c|c|c|}
\hline Item & Control $^{1)}$ & Treatment $^{2)}$ & $\begin{array}{l}\text { Significances }{ }^{4)} \\
\text { (control vs. treatment) }\end{array}$ \\
\hline \multicolumn{4}{|l|}{ Dry matter intake(DMI), $\mathrm{kg} / \mathrm{d}$} \\
\hline Actual & $23.8 \pm 1.2^{3)}$ & $22.7 \pm 0.9$ & NS \\
\hline Recommended & $21.3 \pm 0.8$ & $22.2 \pm 0.9$ & NS \\
\hline \multicolumn{4}{|l|}{ Net energy for lactation $\left(\mathrm{NE}_{\mathrm{L}} \mathrm{I}\right)$, Mcal/d } \\
\hline Actual & $36.2 \pm 1.6$ & $34.9 \pm 1.4$ & NS \\
\hline Recommended & $30.0 \pm 1.5$ & $31.2 \pm 1.6$ & NS \\
\hline \multicolumn{4}{|l|}{ Metabolizable protein intake(MPI), g/d } \\
\hline Actual & $2,308 \pm 118$ & $2,224 \pm 104$ & NS \\
\hline Recommended & $2,191 \pm 111$ & $2,136 \pm 120$ & NS \\
\hline \multicolumn{4}{|l|}{ Significances $^{5)}$} \\
\hline Actual vs. recommended in DMI & $* *$ & NS & \\
\hline Actual $v s$. recommended in $\mathrm{NE}_{\mathrm{L}} \mathrm{I}$ & $* * *$ & NS & \\
\hline Actual vs. recommended in MPI & NS & NS & \\
\hline \multicolumn{4}{|c|}{$\begin{array}{l}{ }^{1)} \text { Control : Lactating cows fed ad libitum TMR. } \\
\text { }{ }^{2)} \text { Treatment : Lactating cows fed restricted TMR. } \\
{ }^{3)} \text { Mean } \pm \text { standard error. } \\
{ }^{4)} \text { Significances were analyzed by t-test (NS, not } s\end{array}$} \\
\hline
\end{tabular}


Table 5. Evaluation of milk yield of Holstein lactating cows fed ad libitum or restricted basal TMR through NRC (2001)

\begin{tabular}{|c|c|c|c|}
\hline Item & Control $^{1)}$ & Treatment $^{2}$ & $\begin{array}{c}\text { Significance }{ }^{4)} \\
\text { (control vs. treatment) }\end{array}$ \\
\hline Actual milk yield, $\mathrm{kg} / \mathrm{d}$ & $27.6 \pm 2.0^{3)}$ & $28.1 \pm 2.3$ & NS \\
\hline $\mathrm{NE}_{\mathrm{L}}$ allowable milk yield, $\mathrm{kg} / \mathrm{d}$ & $36.1 \pm 1.9$ & $33.2 \pm 1.9$ & NS \\
\hline MP allowable milk yield, $\mathrm{kg} / \mathrm{d}$ & $29.9 \pm 1.8$ & $29.0 \pm 1.8$ & NS \\
\hline \multicolumn{4}{|l|}{ Significance in milk yield ${ }^{5)}$} \\
\hline Actual vs. $\mathrm{NE}_{\mathrm{L}}$ allowable & $* * *$ & $* * *$ & \\
\hline Actual vs. MP allowable & NS & NS & \\
\hline
\end{tabular}

${ }^{1)}$ Control : Lactating cows fed ad libitum TMR.

${ }^{2)}$ Treatment : Lactating cows fed restricted TMR.

${ }^{3)}$ Mean \pm standard error.

${ }^{4)}$ Significances were analyzed by t-test(NS, not significant).

${ }^{5)}$ Significances were analyzed by paired $\mathrm{t}$-test(NS, not significant; $\left.* * * \mathrm{p}<0.001\right)$.

및 $\mathrm{MP}$ 를 공제한 양으로부터 추정한 생산 가능한 유 량 $\left(\mathrm{NE}_{\mathrm{L}}\right.$ and $\mathrm{MP}$ allowable milk yield)은 대조구가 실제 유생산량보다 각각 $30.7 \%$ 와 $8.2 \%$ 를 더 많이 생산하는 것으로 나타났고, 시험구는 실제 유생산량보다 $17.9 \%$ 와 $6.6 \%$ 가 더 많이 생산되는 것으로 나타났다.

$\mathrm{NRC}$ (2001)가 권장하는 $\mathrm{NE}_{\mathrm{L}}$ 및 $\mathrm{MP}$ 섭취량보다 많 이 섭취 하였음에도 불구하고, actual milk yield가 $\mathrm{NE}_{\mathrm{L}}$ 및 MP AMY 보다 낮게 나타난 것은 착유우의 유전적 개량으로 인한 섭취량의 증가 및 사육환경 등에 따른 유지를 위한 에너지 분배량이 NRC(2001)가 권장한 유지에너지 권장량보다 많았기 때문이라 생각된다. Agnew 등 (2003)은 유지에너지 권장량 (NEm)을 0.095 $\mathrm{Mcal} / \mathrm{kg}^{0.75}$ 로 보고한 바 있으며, 이는 서유럽과 북미에 서 주로 이용되고 있는 Van Es (1978), INRA (1989), $\mathrm{NRC}$ (2001) 등에서 권장하는 $0.070,0.070,0.073$ $\mathrm{Mcal} / \mathrm{kg}^{0.75}$ 및 이에 $\mathrm{NRC}$ (2001)에서 제시한 free stall systems에서 사육되는 착유우의 활동에너지 $10 \%$ 를 더 한 $0.077,0.077,0.081 \mathrm{Mcal} / \mathrm{kg}^{0.75}$ 보다 높았다고 보고 하였다. 본 연구에서의 결과도 Agnew 등 (2003)의 보 고와 유사한 경향을 보였다.

사료섭취 수준의 증가는 반추위내 소화물의 하부장 기로의 통과속도를 증가시키게 되어 반추위 미생물에 의한 분해 시간이 줄어들어 영양소 소화율이 감소하 게 된다(Moe와 Tyrrell, 1972). 본 실험에서 실제 유 생산량, 유지방 및 단백질 생산량은 NRC (2001) 건물 섭취 권장량에 따라 건물섭취 및 영양소를 제한한 시 험구가 대조구보다 높은 경향을 나타내었고, 섭취 영 양소 대비 유생산 효율은 역시 시험구가 대조구보다 높게 나타났다.

이러한 본 실험의 결과에서 판단해 볼 때 농후사료 급여 비율이 높은 착유우에 있어서 건물섭취 및 영양 소 섭취량을 무제한으로 허용하는 것은 오히려 사료 의 이용효율을 감소시켰을 것으로 예측되며, 따라서
유생산을 위한 영양소 이용 효율 역시 감소시키는 것 으로 사료된다.

\section{V. 요 약}

$\mathrm{NRC}$ (2001)의 권장량만큼 건물섭취 및 영양소 공급 량을 제한하였을 경우의 착유우의 영양소 섭취균형 및 생산성을 제한하지 않았을 경우와 비교 조사하였다.

Basal TMR을 무제한 급여한 대조구와 제한 급여한 시험구의 유생산량은 각각 $27.5 \mathrm{~kg}$ /일/두, $28.1 \mathrm{~kg}$ /일/두 로 시험구가 높은 경향을 나타내었고, $4 \% \mathrm{FCM}$ 과 $\mathrm{FPCM}$ 생산량은 각각 $28.0 \mathrm{~kg} /$ 일/두, $27.8 \mathrm{~kg}$ /일/두로 대 조구의 $26.1 \mathrm{~kg}$ /일/두, $26.4 \mathrm{~kg}$ /일/두 보다 높은 경향을 나타내었으나 통계적 유의차는 나타나지 않았다. 대조 구의 실제 건물섭취량은 $23.8 \mathrm{~kg}$ /일/두로 시험구의 22.7 $\mathrm{kg} /$ 일/두 보다 많이 섭취하였고, 대조구의 실제 건물섭 취량은 NRC (2001)의 건물섭취 권장량보다 많이 섭취 하는 것으로 나타났다 $(\mathrm{P}<0.01) . \mathrm{NRC}(2001)$ 로 추정한 대조구의 $\mathrm{NE}_{\mathrm{L}}$ 실제섭취량은 $36.2 \mathrm{Mcal} /$ 일/두로 시험구 의 $34.9 \mathrm{Mcal} /$ 일/두 보다 높은 경향을 나타내었으며, $\mathrm{NRC}$ (2001)로 추정한 대조구와 시험구의 $\mathrm{NE}_{\mathrm{L}}$ 실제섭 취량은 $\mathrm{NRC}$ (2001)의 $\mathrm{NE}_{\mathrm{L}}$ 섭취권장량 보다 모두 높게 나타났다 $(\mathrm{P}<0.001)$. NRC (2001)로 추정한 대조구의 MP 실제섭취량은 $2308 \mathrm{~g} /$ 일/두로 시험구의 $2224 \mathrm{~g}$ /일/ 두 보다 높은 경향을 나타내었으며, NRC (2001)로 추 정한 대조구와 시험구의 $\mathrm{MP}$ 실제섭취량은 $\mathrm{NRC}$ (2001)의 MP 섭취권장량 보다 모두 높게 나타났으나 통계적 유의차는 나타나지 않았다.

이러한 본 실험의 결과에서 판단해 볼 때 농후사료 급여 비율이 높은 착유우에 있어서 건물섭취 및 영양 소 섭취량을 무제한으로 허용하는 것은 오히려 사료 의 이용효율을 감소시키는 것으로 예측되며, 따라서 유생산을 위한 영양소 이용 효율 역시 감소시키는 것 
으로 사료된다.

\section{VI. 인 용 문 헌}

1. Agnew, R. E., Yan, T., Murphy, J. J., Ferris, C. P. and Gordo, F. J. 2003. Development of maintenance energy requirement and energetic efficiency for lactation from production data of dairy cows. Livest. Prod. Sci. 82:151-162.

2. Association of Official Analytical Chemists. 1990. Official methods of analysis. 15th edn. A.O.A.C., Arlington, VA.

3. Gordon, F. J. 1981. Feed input-milk output relationships in the spring-calving dairy cow. In: Haresign, W. (Ed.), Recent Advances in Animal Nutrition-1980. 15-31. Butterworths, London.

4. Institut National De la Recherche Agronomique (INRA). 1989. Ruminant Nutrition-Recommended Allowances and Feed Tables. John Libbey Eurotext, Paris-London-Rome, France.

5. Licitra, G., Hernandez, T. M. and Van Soest, P. J. 1996. Standardization of procedures for nitrogen fractionation of ruminant feeds. Anim. feed Sci. Technol. 57:347-358.

6. Mayne, C. S. and Gordon, F. J. 1984. The effect of type of concentrate and level of concentrate feeding on milk production. Anim. Prod. 39:65-76.

7. Mertens, D. R. 2002. Gravimetric determination of amylase-treated neutral detergent fiber in feeds with refluxing in beakers or crucibles: collaborative study.
JAOAC. 85:6.

8. Moe, P. W. and Tyrrell, H. F. 1972. The net energy value of feeds for lactation. J. Dairy Sci. 55:945-958.

9. NRC. 2001. Nutrient Requiremente of Dairy Cattle (7th Ed.). National Academy Press, Washington, D. C.

10. O’Mara, F. P., Murphy, J. J. and Rath, M. 1998. Effect of amount of dietary supplement and source of protein on milk production, ruminal fermentation and nutrient flows in dairy cows. J. Dairy Sci. 81:2430-2439.

11. Rim, J. S., Lee, S. R., Cho, Y. S., Kim, E. J., Kim, J. S. and Ha, Jong K. 2008. Prediction of dry matter intake in lactating Holstein dairy cows offered high levels of concentrate. Asian-Aust. J. Anim. Sci. 21(5):677-684.

12. Rinne, M., Jaakkola, S., Kaustell, K., Heikkila, T. and Huhtanen, P. 1999b. Silages harvested at different stages of grass growth $v$. concentrate foods as energy and protein sources in milk production. Anim. Sci. 69:251-263.

13. SAS. 2001. SAS User's Guide: Statistical Analysis Systems Institute, Inc. Cary, NC.

14. Tyrrell, H. F. and Moe, P. W. 1975. Effect of intake on digestive efficiency. J. Dairy Sci. 58:1151-1163.

15. Van Es, A. J. H. 1978. Feed evaluation for ruminants. 1. The systems in use from May 1977 onwards in the Netherlands. Livest. Prod. Sci. 5:331-345.

(접수일자 : 2007. 8. 9. / 수정일자 : 2009. 2. 9. / 채택일자 : 2009. 2. 13.) 